\title{
The Role of Computer Technology in E-commerce Network Consumption Interaction
}

\author{
Xu Hailong \\ Jiangxi College Of Foreign Studies
}

\begin{abstract}
Mankind has currently entered information-based society. Informatization is the feature of modern society, while the base of informatization lies in the application of computer technology and network technology. E-commerce has extensively existed in all levels of commodity transaction. This paper aims to probe into the application mode and matters needing attention of computer technology in E-commerce network consumption interaction and explore functions of e-commerce through summarizing the significance of computer technology in e-commerce. Specifically speaking, computer technology can reduce commercial tenants' costs, increase buyer and seller's communication efficiency and also expand merchants' scope of advertising. Computer technology can construct and manage e-commerce website, make and sell virtual goods and services to increase buyer and seller's interactive efficiency. Application of technology should pay attention to improve the importance of computer security technology, strengthen communication between buyer and seller and focus on training mode of computer technology talents. Through summary and discussion of questions above, this paper considers that computer technology plays an important role in e-commerce network consumption interaction.
\end{abstract}

Keywords-Computer technology; E-commerce; Network consumption

\section{INTRODUCTION}

E-commerce expenditure of China grows year by year and the total consumption in 2014 has already surpassed 13 trillion. Compared to traditional pattern of consumption, e-commerce consumption has more advantages. To merchants, it is able to reduce operating and management costs. To consumers, shopping and payment can be more convenient. E-commerce technology based on computer technology can realize trans-regional and inter-time transactions to enable consumers to enjoy cheaper commodity service and help merchants gain more profits.

The global society has entered information-based society, which is characterized by the application of computer technology. Computer technology has penetrated into every aspect of human life. Network technology, which is closely related to computer, has offered multiple kinds of information, enabling people to read latest information and even experience visiting service at home. E-commerce refers to the commercial activity taking information network technology as means and commodity exchange as center. E-commerce can be regarded as the informatization of traditional commercial activity. Compared to traditional commercial activity, e-commerce can realize 24-hour open and require fewer costs such as human cost and rental, thus e-commerce becomes a rising entrepreneurial way. The foundation of e-commerce is computer technology. Whether it is website construction, propaganda, maintenance, messages sending and receiving, they all need computer technology-based computer technology. Generally speaking, perfect computer technology has significances including reducing merchants' costs, increasing communication efficiency, expanding the scope of advertising, facilitating order completion, reducing shopping process and increasing merchants' profit, etc.

This paper mainly elaborates the application of computer technology in e-commerce consumption interaction and its positive role in e-commerce network consumption. 


\section{FUNCTIONS OF E-COMMERCE}

E-commerce based on computer technology and network technology runs through every aspect of network consumption interaction and can offer all-round services including web browsing, internet payment and network management, and both of its merchant's selling experience and buyer's shopping experience are superior to that of traditional consumption patterns. Specifically speaking, e-commerce has four functions: firstly, consumers can order goods and automatically create orders on the internet through e-commerce website. They only need to collect and confirm goods, instantly create complete orders and finally present to merchant's interface. Secondly, e-commerce has internet payment function. Early internet payment function mainly used electronic credit card account, but current internet payment has diversified channels, including e-bank and various e-wallets, and all can complete payment successfully. Thirdly, e-commerce can release advertisements to publicize. Merchants can propagandize with the help of e-mail ads and website ads. Fourthly, e-commerce can manage transaction. It realizes the communication among human resources, finance, manager and consumer and manages through rational division of labor. The foundation of various above-mentioned functions of e-commerce is that it fully takes advantage of computer technology and gives full play to functions of computer technology.

Basic Framework of E-commerce Website

To every consumption website, a rational and complete basic framework is necessary, while every part of framework integrates with computer technology. As shown in the Figure 1 e-commerce consumer system, every module is embedded into the application of computer technology.

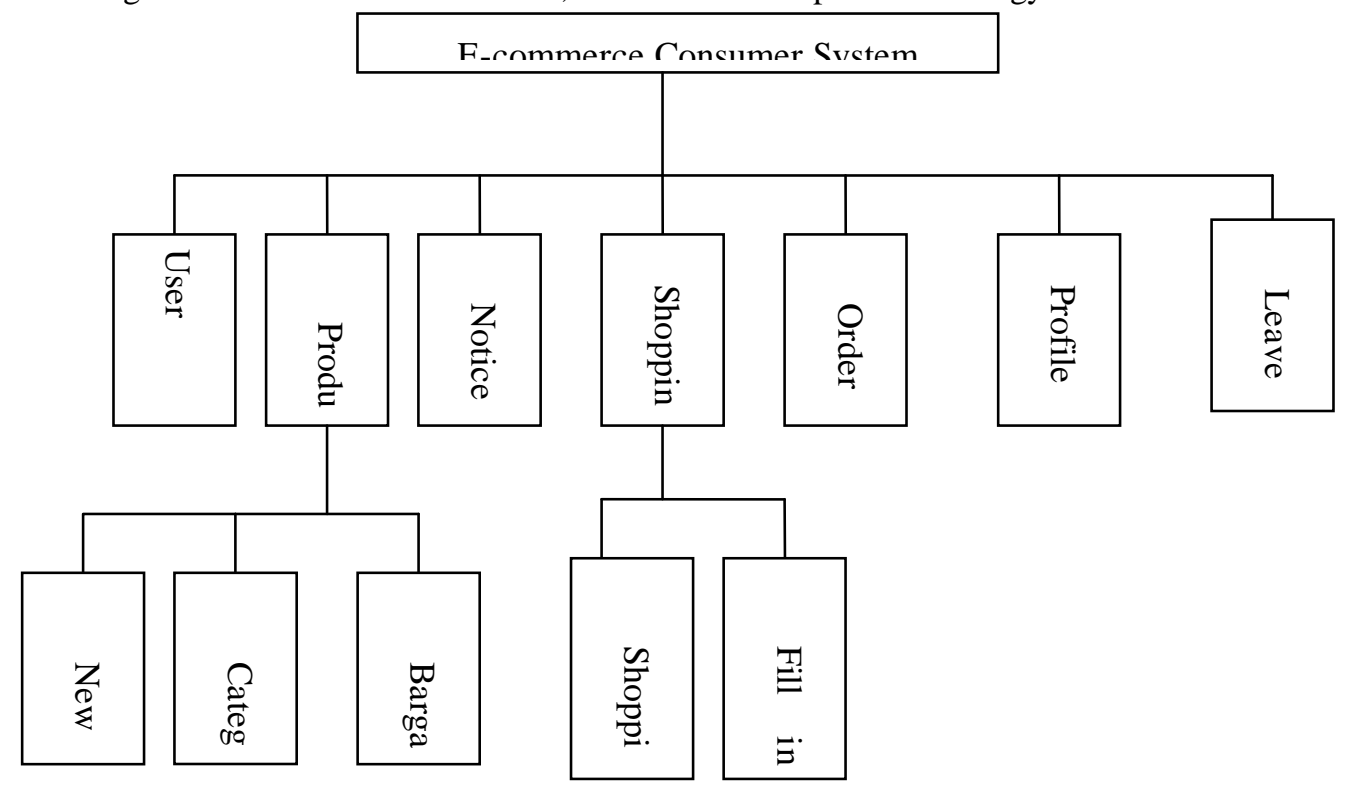

Figure 1. E-commerce Consumer System

\section{COMBINATION AND APPLICATION OF MODERN} TECHNOLOGY AND COMPUTER TECHNOLOGY

\section{A. Integration and Professionalization}

From recognizing objective world to transforming objective world, the contradiction of professionalization and integration has been formed. On the one hand, it requires getting deep into the objective and careful division of labor of science and technology. On the other hand, it has to integrate subdivided professions to adapt to national policy and economy. After all, a lot of work can't be done by one profession. Intensify integration and professionalization so that electronics technology infiltrating into national life won't cause great perplex or chaos.

\section{B. Infiltrating into Various Fields}

Computer science and technology has become absolute productivity of modern society. Software Company is the best example. Computer science and technology has infiltrated into various fields including military, industry, life and education, and these fields develop faster with the 
participation of computer science and technology. It can be said that computer science and technology has promoted development of various fields, while the development demand of other fields also drives the progress of computer science and technology.

\section{More Humanized}

The development of times makes people have higher requirement for computer science and technology, including humanized requirement. Computer in the new era has to possess good man-machine coordination ability and provide utmost convenience for users, so much so that people can use language or gesture to command computer's operation. Humanization of computer science and technology is not only the manifestation of people's pursuit of convenient life, but also the future development tendency.

\section{CONCLUSION}

China's e-commerce industry has already gained rapid development and even been expanding overseas market. With such environmental requirement, computer requires better popularization and development. Only by keeping its technology's advancement can it make a contribution to China's e-commerce industry. To sum up, this paper comes to following conclusions:

1. E-commerce's rapid development can't be achieved without its combination with computer technology. To attract more people's attention to website, it also needs optimization of website other than the establishment of a complete website.

2. Computer technicians have to continuously research and develop more advanced and perfect new technology to promote e-commerce upgrade. Only by guaranteeing the advancement of computer technology can it guarantee the security for the development of China's e-commerce network consumption and its green development.

\section{REFERENCES}

[1] Sarrafzadeh M. Department Of Electrical Engineering And Computer Science[J]. Journal of Chemical Education, 2001, 3(6):II - 1001-4.

[2] Dan G. Algorithms on Stings, Trees, and Sequences: Computer Science and Computational Biology.[J]. Quarterly Review of Biology, 1997, 28(3):41-60.

[3] Weiser M. Some computer science issues in ubiquitous computing $[\mathrm{J}]$. Acm Sigmobile Mobile Computing \& Communications Review, 1993, 36(7):74-84.

[4] Chen, X. (2006). Department of computer science and technology. Journal of Henan Mechanical \& Electrical Engineering College.

[5] Newell A, Simon H A. Computer Science as Empirical Inquiry: Symbols and Search.[J]. Communications of the Acm, 1976, 19(3):113-126.

[6] Dan, Gusfield. "Algorithms on Stings, Trees, and Sequences: Computer Science and Computational Biology.." Quarterly Review of Biology 28.3(1997):41-60.

[7] Petkov, V., and M. Mikhov. "Magnetic phase diagram of the MnAs spin system. A computer simulation." Journal of Physics C Solid State Physics 18.19(1985):3791-3795.

[8] Kalinowski, STEVEN T., M. L. Taper, and T. C. Marshall. "Revising how the computer programcer vusac commodates genotyping error increases success in paternity assignment." Molecular Ecology 16.5(2007):1099-1106(8).

[9] Berk R A, Schoenberg F. Workshop on statistical approaches for the evaluation of complex computer models[J]. Statistical Science, 2002:173-192.

[10] Bernstein FC; Koetzle TF; Williams GJ; Meyer EF Jr; Brice MD; Rodgers JR; Kennard O; Shimanouchi T; Tasumi M. (1978). The protein data bank: a computer-based archival file for macromolecular structures. Archives of Biochemistry \& Biophysics, 185(2), 584-591.

[11] Saltzer, J. H., and Schroeder, M.D. "The protection of information in computer systems." Proceedings of the IEEE 63.9(1975):1278-1308

[12] Farin G, Farin G. Curves and surfaces for computer aided geometric design - a practical guide (3. ed.).[J]. Academic Press Inc Boston Ma, 1993. 